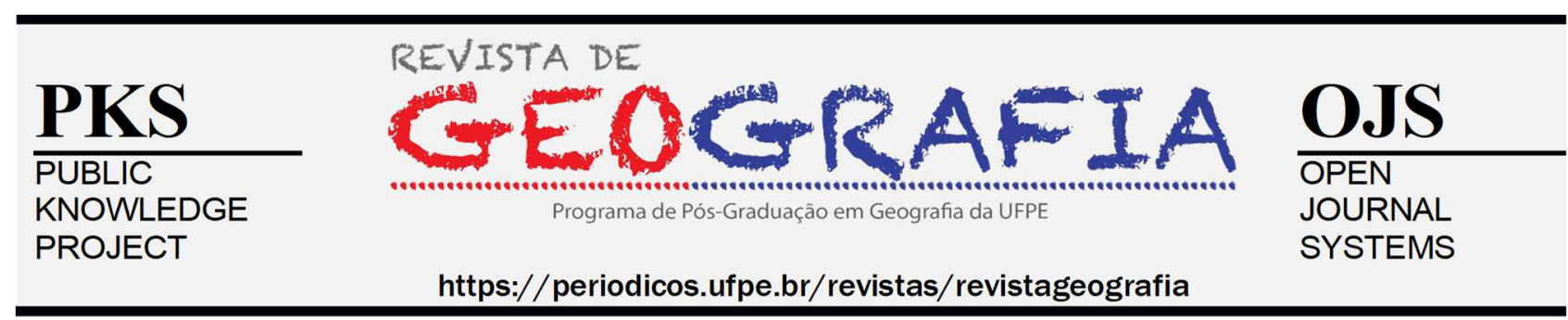

\title{
PLUVIOMETRIC VARIABILITY, WATER BALANCE AND RISK OF DRY SPELLS IN THE BASIN OF PARANÁ RIVER III, BRAZIL
}

\author{
Nathan Felipe da Silva Caldana ${ }^{1}$, Marcelo Augusto Aguiar e Silva ${ }^{2}$ Mateus Galvão Cavatorta ${ }^{3}$, \\ Luiz Gustavo Batista Ferreira ${ }^{4}$, Jorge Alberto Martins ${ }^{5}$
}

\begin{abstract}
${ }^{1} \mathrm{PhD}$ student in Agronomy at the State University of Londrina. E-mail: nathan.caldana@uel.br. orcid.org/0000-00032837-4621

${ }^{2} \mathrm{PhD}$, Adjunct Professor at the State University of Londrina. E-mail: aguiaresilva@uel.br. https://orcid.org/0000-00033835-1124

3 Master's student in Geography at the State University of Londrina. E-mail: cavatortamateus@gmail.com. https://orcid.org/0000-0001-5001-8928

${ }^{4}$ Master in Conservation Agriculture at the Agronomic Institute of Parana, E-mail: luiz.gustavo@agronomo.eng.br. https://orcid.org/0000-0002-0851-2524

$5 \mathrm{PhD}$, Adjunct Professor at the Federal University of Technology - Paraná. E-mail: jmartins@utfpr.edu.br. https://orcid.org/0000-0003-4284-0676
\end{abstract}

Artigo recebido em 02/04/2020 e aceito em 28/02/2021

\begin{abstract}
For the agriculture context, the water balance and precipitation analysis are essential for planning and decision-making. The objective of this work was to carry out the analyse of pluviometric variability, climatological water balance (CLIMWB) and the occurrence of dry spells in the Basin of Paraná River III, Paraná State, Brazil. For this purpose, 43 meteorological data from 43 stations, from 1976 to 2018, were used. Geoprocessing techniques were applied to regionalize rain data, in addition to box plots and probabilities to analyze precipitation and the occurrence of dry spells. A signficant precipitation variability was identified with regional and temporal discrepancies. Despite the Basin of Paraná River III is a rainy region in the Paraná State, the occurrence of dry spells was identified. Periods of 20 to 30 days with no precipitation event in the region they were also frequent, due the annual occurrence risks ranging from 80 to $50 \%$, respectively. The risk of 40 consecutive days without rain has already proved to be nil. The water balance exhibited sufficient values for agricultural practice with water surplus along the Basin. However, when analyzing dry years, a water deficit of more than $100 \mathrm{~mm}$ in a single month can occur.
\end{abstract}

Keywords: Agrometeorology; Agricultural planning; Climate variability.

\section{VARIABILIDADE PLUVIOMÉTRICA, BALANÇO HÍDRICO E O RISCO DE SECA NA BACIA DO RIO PARANÁ III, BRASIL}

\section{RESUMO}

O balanço hídrico e a análise da precipitação são fundamentais para o planejamento e tomada de decisões no contexto agrícola. O objetivo deste trabalho foi analisar variabilidade pluviométrica, o balanço hídrico climatológico (BHC) e a ocorrência de veranicos na bacia hidrográfica do Rio Paraná III. Utilizou-se para esse estudo 43 estações meteorológicas com o recorte temporal de 1976-2018. Aplicou-se técnicas de geoprocessamento para a regionalização dos dados de 
chuva, além de box plot e probabilidades para analisar a precipitação e a ocorrência de secas e veranicos. Identificou-se variabilidade da chuva com discrepantes regionalmente e temporalmente. Mesmo sendo uma região chuvosa do Estado, a ocorrência de veranicos se mostra alta em determinadas épocas do ano. Períodos de 20 a 30 dias sem chuva na região também se mostraram frequentes, com risco de ocorrência anual variando de 80 a $50 \%$, respectivamente, no entanto, o risco de 40 dias consecutivos sem chuva se mostrou nulo. $\mathrm{O}$ balanço hídrico apresentou valores suficientes para a prática agrícola com excedente hídrico em toda a região. Entretanto, ao analisar anos secos, há a a possibilidade de ocorrência de $100 \mathrm{~mm}$ de déficit hídrico.

Palavras-chave: Agrometeorologia; Planejamento agrícola; Variabilidade climática.

\section{INTRODUCTION}

Global climate change is a scientific consensus due the climatic evidences and several studies published across the world (MARENGO, 2009). These changes have caused atypical and global extreme events, as occurrences of extreme temperatures, heat waves, drought events, an increase in the heights of daily precipitation, culminating in severe heat or cold risks, in addition, severe storms and floods. The warmest periods in the entire planet, were seen successively in the last three decades, and for precipitation the uncertainties are significant, where the trends point to increase or decrease, according to the geographic position (IPCC, 2014). Rainfall has a key importance for characterizing the climate, interfering with various aspects and activities related to society. Excess or scarcity of rainfall can cause significant losses for environment and for economics (DINIZ, 2013; DA SILVA DIAS, 2014; CALDANA et al., 2018).

The water availability of a region can be quantified by the climatic water balance (CLIMWB). This method exhibits the seasonal variations of water necessities and deficiencies, thus, it is crucial for agricultural planning and decision-making (SOUZA et al., 2013). The studies should be developed with the purpose to aid and improve the relations soil - plant - atmosphere, allowing an adjustment of agricultural practices to the climatic conditions, in addition, exhibiting agricultural applications for the definition of agroclimatic risk zoning, irrigation projects, hydrology, reservoir sizing, drainage, among others (PEREIRA et al., 2002; DANTAS et al., 2007).

Several studies exhibited the climatic impacts, especially pluviometric variability, for agricultural production and, in addition, for urban hydrological system (THORNTON et al., 2011; ADHIKARI et al., 2015; SERDECZNY et al., 2016; DONG et al., 2019; FITTON et al., 2019; GEBRECHORKOS et al., 2019; KANG et al., 2019; MALLUCCI et al, 2019; SATGÉ et al., 2019; SIAD et al., 2019; SUN et al., 2019). In addition, with a high level of confidence and strong regional variation, agricultural productivity is expected to decline in the 21 st century with the projected change in climate, linked to the increase in temperature, extreme meteorological events and the increase in the levels and area of degraded soils (FOLHES; DONALD, 2007; NIANG et al., 2014; IPCC, 2014, 
ADHIKARI et al., 2015; XIE et al., 2019; ZHANG et al., 2019).

For urban space, natural disasters can occur as a consequence of extreme scenarios of precipitation and are defined as nature phenomena which can change the landscape and geographical space (CALDANA et al., 2018). The floods are the most common among hydroclimatological events, with $59 \%$ of the records, thus, the key cause of climatic catastrophes. These climatic events affect the humanity due the way societies organize considering the rhythm and variability of the atmospheric system (VICENTE, 2005, MARCELINO, 2007).

Severe atmospheric instabilities generate large amounts of rain in a short time, in addition, the low drainage of urban spaces and the occupation of inadequate areas are responsible for such events (CIDADE et al., 2013; FREIRE et al., 2014; GRIGOLETTI et al. 2018). In cases of drought, low relative humidity can cause damage to human, animal and crops (SATO et al., 2003).

The Paraná state, South of Brazil, is located in an area of climatic transition, with wide variations in altitude and latitude, thus conditioning large discrepancies in the climate. The purpose of this work was to analyze rainfall variability, water balance and the occurrence of dry spells in the basin of Paraná River III.

\section{MATERIAL AND METHODS}

\section{Climate Variability}

The hydrographic basin of Paraná River III is located in a Cfa climate, which means that it has a humid subtropical climate according to the Köppen climate classification (NITSCHE et al., 2019). This is characterized by the absence of drought seasons and by summers with higher average temperatures. This climate is controlled by air masses from tropical regions (the Atlantic Tropical Mass and the Continental Tropical Mass) and the Atlantic Polar Mass. In addition, the Continental Equatorial Mass can influence the Cfa climate zone during the summer season. Due to the temperature and humidity differences in these climatic masses, the area of the basin is a convergence zone for these climatic front systems, particularly in the winter season period (NITSCHE et al., 2019). 
FIGURE 1. HYPSOMETRY AND LOCATIONS OF STATIONS IN THE HYDROGRAPHIC BASIN OF THE PARANÁ RIVER III

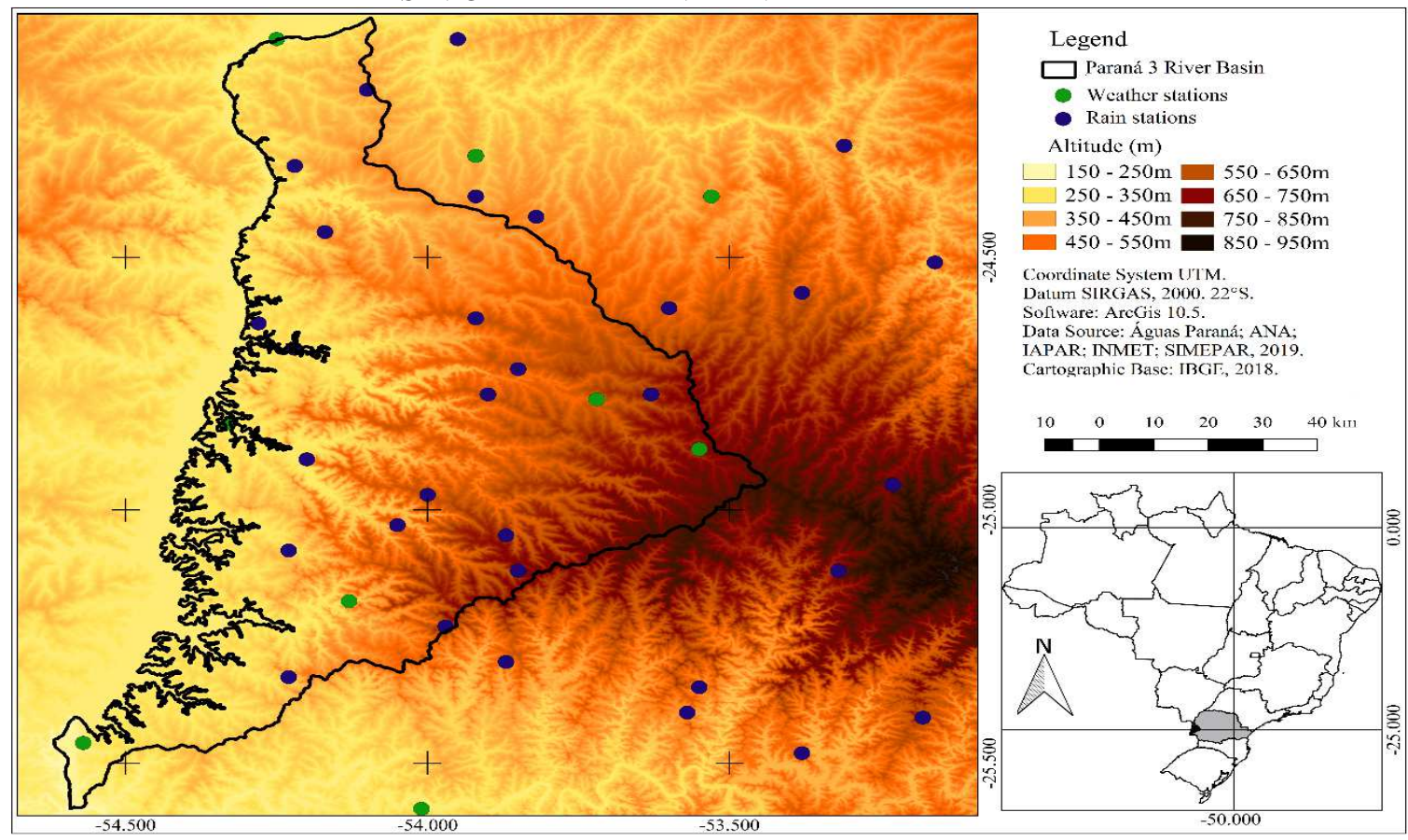

For this purpose, we selected the species hydroclimatic requirements species and weather data of annual, seasonal, monthly, and daily time series from 1976 to 2018. In addition, we surveyed the analyze climate variability and produce the climate risk zoning, data from meteorological stations distributed around the basin. The database comprises data from several weather stations, including six from IAPAR - Instituto Agronomico do Paraná (Brazil) stations (data from 1976 to 2018), ten SIMEPAR—Sistema Meteorológico do Paraná (Brazil) stations (data from 2000 to 2018 were included to contribute to analyses, despite it is a short period of series), and 27 Águas Paraná (Brazil) stations (data from 1976 to 2018); see Figure 1.

The spatialization of these data was carry out by interpolation, which is an effective method for spatial visualization of climate data. This was done using isohyets and/or by spatially filling the values through adjusted regression statistics, using the inverse distance weighted spatial interpolation algorithm (LEM et al., 2013). The maps were created using QGIS software.

We used Box Plot graphs or box diagrams to complement the analysis of rainfall variability and detection of climate extremes. The key resource obtained in its use is to provide a quick view of the data distribution. If the distribution is symmetrical, the box is balanced with the median positioned in the center of the box. For asymmetric distributions, there is an imbalance in the box with respect to the median (SILVESTRE et al., 2014). We created the graphs using the Statistica ${ }^{\circledR}$ software.

The Box plots represent five classifications of values. Discrepancies are divided into outliers (values above what is considered maximum, however not extreme) and extremes, with any values 
greater than Q3 + 1.5 (Q3 - Q1) or less than Q1 - 1.5 (Q3 - Q1). The highs and lows are considered the highest values in the series, however they are not extreme or outliers. Inside the box, three quartiles are classified with $25 \%$ of the data each, in addition to the median value, equivalent to the second quartile, or $50 \%$ of the data (LEM et al., 2013; SCHNEIDER and DA SILVA, 2014).

For the analysis using Box plot, we used data from the municipalities of Matelândia, Santa Lucia, Terra Roxa and Toledo, taking the different rainfall values as a parameter from the area under the study (Figure 4).

In order to identify the probability of occurrence of dry spell, the frequencies of the number of consecutive days with precipitation equal to or less than $1 \mathrm{~mm}$. day ${ }^{-1}$ or $10 \mathrm{~mm}$. day ${ }^{-1}$, with duration of at least 10 days were determined. Frequency analyzes were carried out using mobile decendial (110 / 01, 2-11 / 01, 3-12 / 01, and subsequently). This procedure avoids the omission of consecutive December periods without rain that can occur when considering only the ten days 1-10, 11-20 and 20-30 of each month. Only values above than or equal to $1 \mathrm{~mm}$ we considered as rainfall.

In the data series, we verified the occurrences of consecutive periods without rain lasting 20 days or more and the longest dry period of each year. Rainy days were those in which the precipitation was equal to or greater than $1.0 \mathrm{~mm}$. A descriptive analysis of the mean of the events that had 20 days or more without rain was also made, in addition to the error and standard deviation. The frequencies of the dry periods and the adjustment of the largest annual dry period to the distribution of extreme values were calculated, whose probability density function $\mathrm{f}(\mathrm{X})$ and the cumulative function of probability $\mathrm{F}(\mathrm{X})$ have the following format (ASSIS et al., 1996; COSTA et al., 2009):

$$
\begin{gathered}
f(X)=\frac{1}{\beta} e^{-\frac{x-a}{\beta}} e^{-e^{-\frac{x-a}{\beta}}} \\
F(X)=\frac{1}{\beta}-e^{-\frac{x-a}{\beta}}
\end{gathered}
$$

We accepted " $\mathrm{X}$ " as the random variable, $\alpha$ is the parameter that controls the position of the curve on the abscissa axis and $\beta$ is the parameter that controls the dimensions of the curve, given a constant shape. We also used the Lieblein method to estimate the $\alpha$ and $\beta$ parameters and the Kolmogorov-Smirnov adherence test, as described by Assis (1996) and Costa et al., (2009). We used as a model the stations of the municipalities of Matelândia, Santa Lucia, Terra Roxa and Bom Princípio (Toledo).

We extracted Rainfall data (from the monthly totals of each year) and the monthly average temperature (from the monthly averages of the daily values of each year). Then, potential evapotranspiration (PET) was calculated according to the Thornthwaite method. Firstly, the standard potential evapotranspiration (PET, $\mathrm{mm} / \mathrm{month}$ ) was calculated using the empirical formula: 


$$
\begin{gathered}
\text { For: } 0<\mathrm{Tn}<26.5^{\circ} \mathrm{C} \\
\text { PET }=16\left(10 \frac{\mathrm{Tn}}{\mathrm{I}}\right)^{\mathrm{a}} \\
\text { For: } \mathrm{Tn} \geq 26.5^{\circ} \mathrm{CTn}^{2} \\
\text { PET }=-41585,+3224, \mathrm{Tn}-43.0 \mathrm{Tn}^{2}
\end{gathered}
$$

Where Tn is the average temperature of month $n$ ( $n=1$ is January, $n=2$ is February, etc.) in ${ }^{\circ} \mathrm{C}$, and $\mathrm{I}$ is an index that expresses the heat level of the region.

The value of I depends on the annual temperature cycle, integrating the thermal effect of each month, and is calculated using the formula

$$
\mathrm{I}=12(0.2 \mathrm{Ta})^{1514}
$$

The exponent "a", being a function of $\mathrm{I}$, is also a regional thermal index, and is calculated using the expression

$$
a=0.49239+1.7912 \times 10^{-2} I-7.71 \times 10^{-5} I^{2}+6.75 \times 10^{-7} I^{3} .
$$

The PET value represents the total monthly potential evapotranspiration that would occur under the thermal conditions of a standard 30-day month, and with a 12-hour photoperiod (N) each day. Therefore, PET should be corrected for $\mathrm{N}$ and the number of days in the period.

$$
C O R=\left(\frac{N}{12}\right)\left(\frac{N D P}{31}\right)
$$

\section{RESULTS AND DISCUSSIONS}

Precipitation in the basin of Paraná River III exhibited a regional discrepancy (Figure 02). We identified the lowest average annual rainfall was $1,550 \mathrm{~mm}$, in the Northern of the Basin (Guaíra), while the highest average values were verified in the municipality of Cascavel region and in part of the Southern region of the basin with precipitation ranging from 2,050 to 2,125 $\mathrm{mm}$. 
FIGURE 2 - ANNUAL AVERAGE RAINFALL IN THE BASIN OF PARANÁ RIVER III

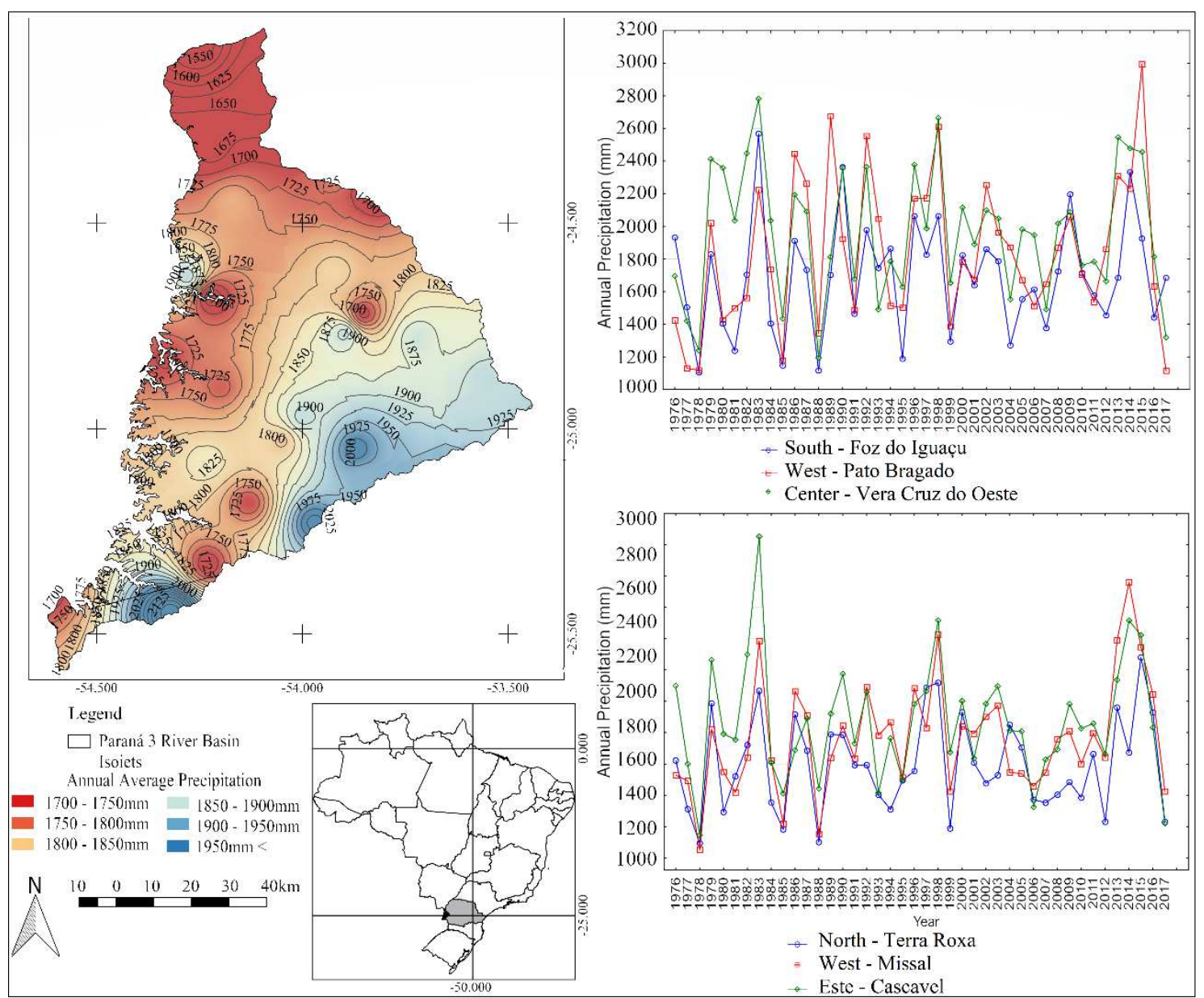

In the Basin of Paraná River III, the precipitation has three predominant forms, causing regional variability. First, the cold fronts, which are characterized by the junction of the Polar Air Mass with the continental hot air mass; with the advent of humidity, they generate a strong atmospheric instability, which can lead to the formation of cumulunimbus and lead to the formation of severe storms, which may be accompanied by strong gusts of wind and precipitation with hail, or even light to moderate (HOLLEMAN, 2001; BEREZUK and SANT'ANNA NETO, 2006; KUNZ et al., 2009; BEREZUK, 2017; PUNGE et al., 2017; SANCHEZ et al., 2017; CALDANA et al., 2018; CALDANA et al., 2019). These operate, basically, during the Fall and Winter.

The Polar Air Mass has a trajectory favored by the trough of the Paraná river and later the Iguaçu River, having a great impact on the local, mainly in the South portion near to the cross of the two rivers in the municipality of Foz do Iguaçu (CALDANA et al., 2018; CALDANA et al., 2019). The cold fronts are identified in satellite images by a line of instability that advances in the Paraná state in the Southwest to Northeast direction. (HOLLEMAN, 2001; BEREZUK and SANT'ANNA NETO, 2006; BEREZUK, 2017; CALDANA et al., 2018; CALDANA et al., 2019). And as noted, the topography in the Southern area of the region increase from 200 to $800 \mathrm{~m}$ (Figure 01); this abrupt 
difference on the topography can bring more rain in the highest region of the basin, near to municipality of Cascavel.

The other two origins of precipitation formation in the region are the Convective Systems and the Mesoscale Convective Complexes - MCC, which operate along the year, however, predominantly in Spring and Summer. The MCCs are identified in satellite images by their approximately circular shape and by a wide area of storm coverage. They are defined as a cluster of cumulunimbus covered by a dense cirrus layer, and are also convective cloud systems, with rapid vertical and horizontal formation over a period of 6 to 12 hours. Depending on the intensity, they can create several storms and hail occurrence (HOLLEMAN, 2001; SCAGLIONI and SARAIVA, 2004; KUNZ et al., 2009; PUNGE and KUNZ, 2016; DAFIS et al., 2017; PUNGE et al., 2017; TREFAULT et al., 2018). Their displacement through Paraná state is normally in the West to East direction, coming from Paraguay (CALDANA et al., 2018; CALDANA et al., 2019). It should be noted that the altitudes of the region also rise, in the West to East direction, which may contribute to the friction of the system with the topography (Figure 01).

Convective systems are differentiated from MCC by the lesser spatial coverage, formed by the process of heat transfer by conduction that occurs in intense vertical movements, thus leading to the rapid condensation process and the formation of Cumulunimbus. In both systems, the friction with the topography can also contribute to the rise of the warmer and humid air, being able to form nuclei of condensation and rain (HOLLEMAN, 2001; MIDDLETON and MCWATERS, 2002; SCAGLIONI and SARAIVA, 2004; KUNZ et al., 2009; DAFIS et al., 2017; TREFAULT et al., 2018).

This explains the highest average rainfall in the highest parts of the region (CALDANA et al., 2018a). With the development and preferential trajectory in the same direction as the MCC, the topography of the region can also contribute to the significant pluviometric heights being located in the highest portion of the region, according to the Figure 1.

To complement the analysis of precipitation in the region, it was worked with the variability through the box plot (Figure 03) and it was possible to verify discrepancy between the pluviometric heights of the Matelândia station for the others. The interval between Q1 and Q3 was 1,290 mm to 2,195 $\mathrm{mm}$. The median was $1,975 \mathrm{~mm}$ and the maximum value was 3,006 $\mathrm{mm}$, with the highest annual rainfall recorded in the series of stations analyzed.

Even with maximum pluviometric height less than the Matelândia station, the medians of the Toledo and Santa Lucia stations exhibited values approximately of Matelândia, with 1,860 and 1,805 $\mathrm{mm}$, respectively. The maximum values observed were also close, with 2,620 and 2,610 mm, respectively. 
FIGURE 3 - ANNUAL PLUVIOMETRIC VARIABILITY IN THE BASIN PARANÁ RIVER III

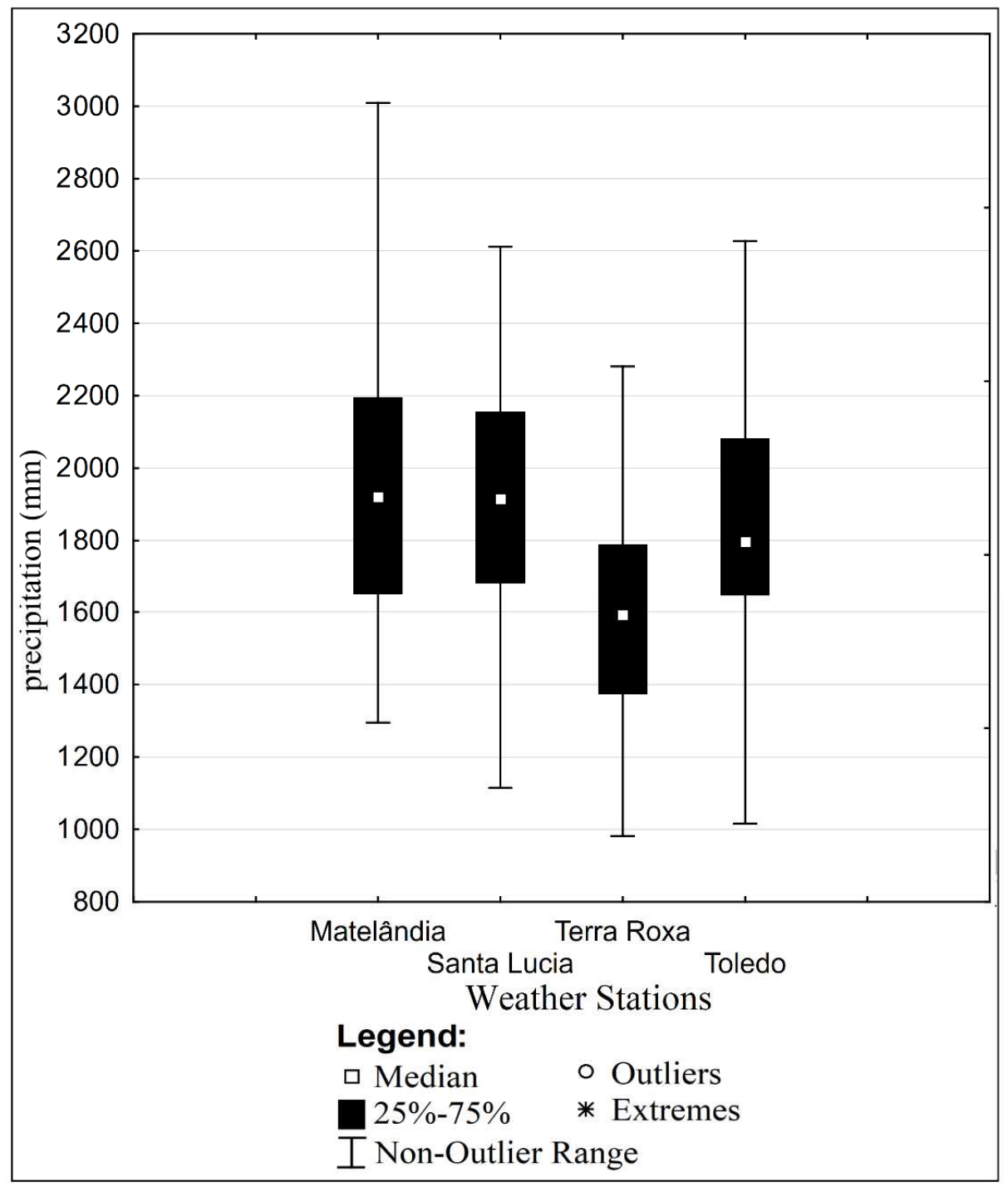

On the other hand, the stations from the municipality of Terra Roxa exhibited values with a relative dispersion. The median was $1,602 \mathrm{~mm}$ and the maximum and minimum values from 2,260 to $960 \mathrm{~mm}$, respectively. The latter was the lowest annual rainfall verified among the analyzed stations. The interval between Q1 and Q3 in Terra Roxa was from 1,798 to 1,385 mm, respectively. Even with the discrepancy between the locations, the basin of Paraná River III was rainy by the annual average, not being a limiting factor for the crops production, however its variability and regional distribution can be limiting aspects.

Monthly, different from other regions of Paraná state that present the rainiest month in January (CALDANA et al., 2018; CALDANA et al., 2019; NITSCHE, 2019), the basin presented the month of October with the highest pluviometric heights and the highest monthly median (Figure 04). 
The Matelândia station showed great variation in the month of May, with an oscillation from $557 \mathrm{~mm}$ in 1992 to $2.5 \mathrm{~mm}$ in 2006. Only August 1999 was verified without rain at this point. Were identified seven discrepancies and one extreme, concentrated mainly in the winter and spring months.

Was verified in municipality of Santa Lucia, the highest monthly rainfall, which occurred in June 2014 with $608 \mathrm{~mm}$. There were five discrepancies and two extremes in this location. Comparatively, there was a difference in the distribution of rainfall between the municipalities of Matelândia and Santa Lucia, as the month of December was rainier than November, in the latter, and February was rainier than May, while in municipality of Terra Roxa there was the smallest monthly variation between Q1 and Q3, mainly in the month of July with a 43mm fluctuation. In contrast, there was a greater concentration of outliers (13) and extremes (5). In Toledo, on the other hand, there was the greatest variation between quartiles, in May, with an oscillation of $202 \mathrm{~mm}$ and $566 \mathrm{~mm}$ between the maximum and minimum values. 
FIGURE 4 - MONTHLY PLUVIOMETRIC VARIABILITY IN THE BASIN OF PARANÁ RIVER III

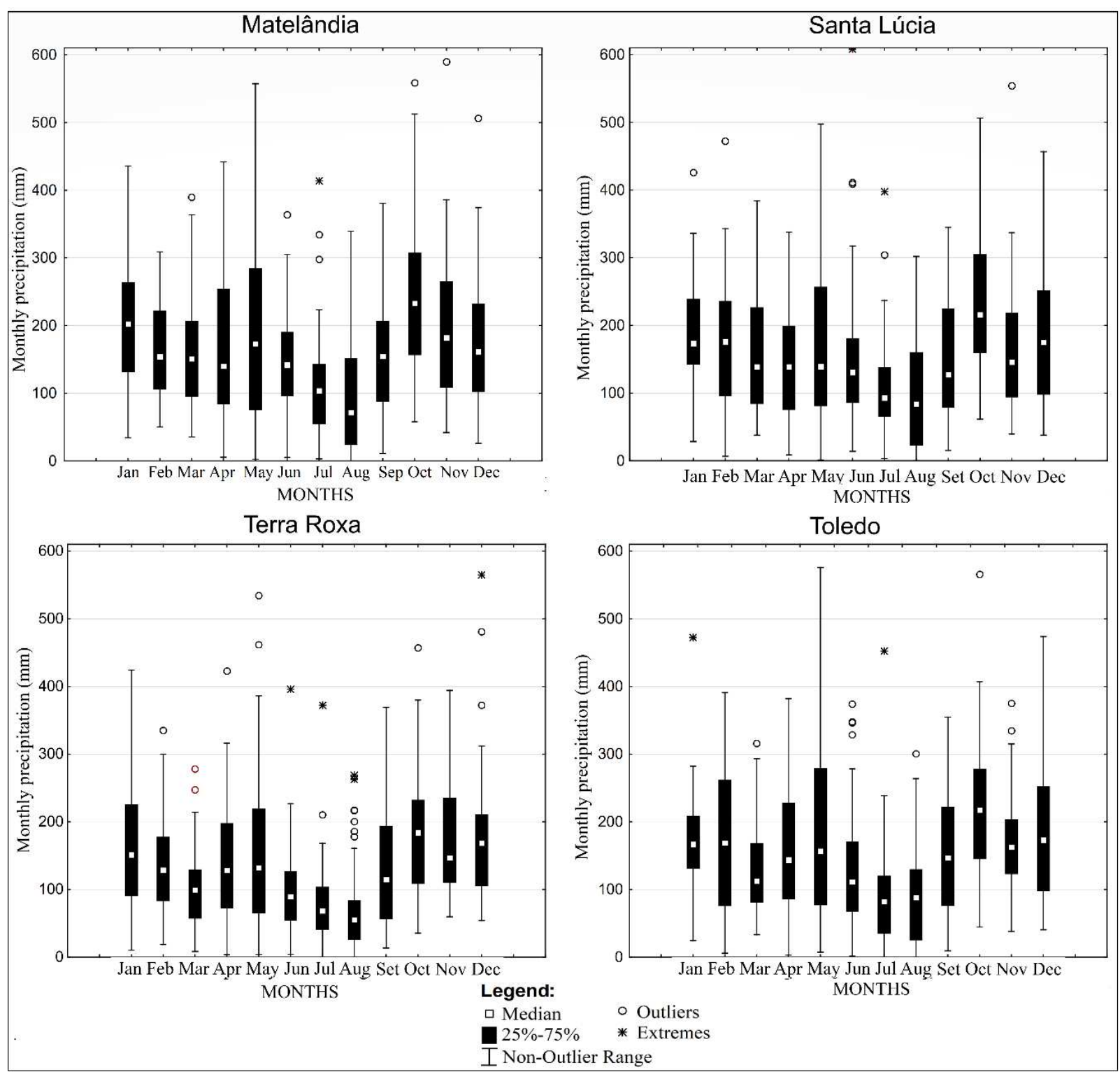

The results exhibit significant monthly variation in precipitation in the region, suggesting the relevance of agroclimatic risk zoning and appropriate agricultural management practices. When verifying scenarios of drought through the relative frequencies of dry spells months in decendial mobile (Figure 5) indicate a variation from zero to more than $60 \%$ of risk of occurrences in the basin of Paraná River III. The periods with the lowest risk are throughout the month of October, followed from December 10 to January 5. 
FIGURE 5 - FREQUENCY OF OCCURRENCES OF DRY SPELLS DURING DECENDIAL SERIES IN THE BASIN OF PARANÁ RIVER III

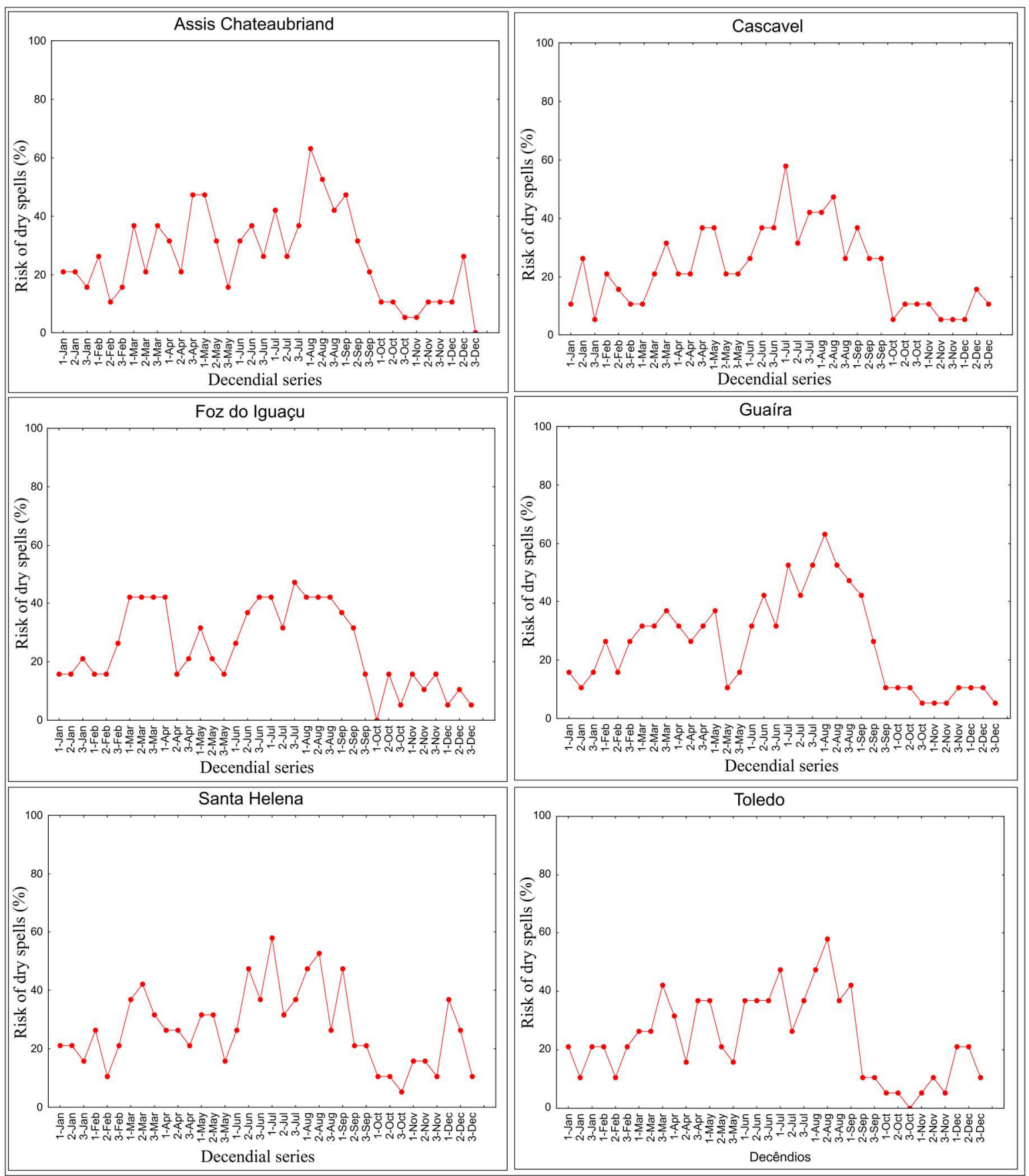

The risks of dry spells are concentrated in August, reaching $60 \%$ and, also, for the first half of September, indicating the necessity of agricultural planning, due its consider the climatic risks and the precipitation variability.

Most years have at least a period of at least 20 consecutive days without rain (Figure 06). The station with the most annual occurrences was identified in the municipality of Terra Roxa, showing 106 occurrences from 1976 to 2017 . Only the year 2000 was not verified at least 20 days without rain in the basin. 


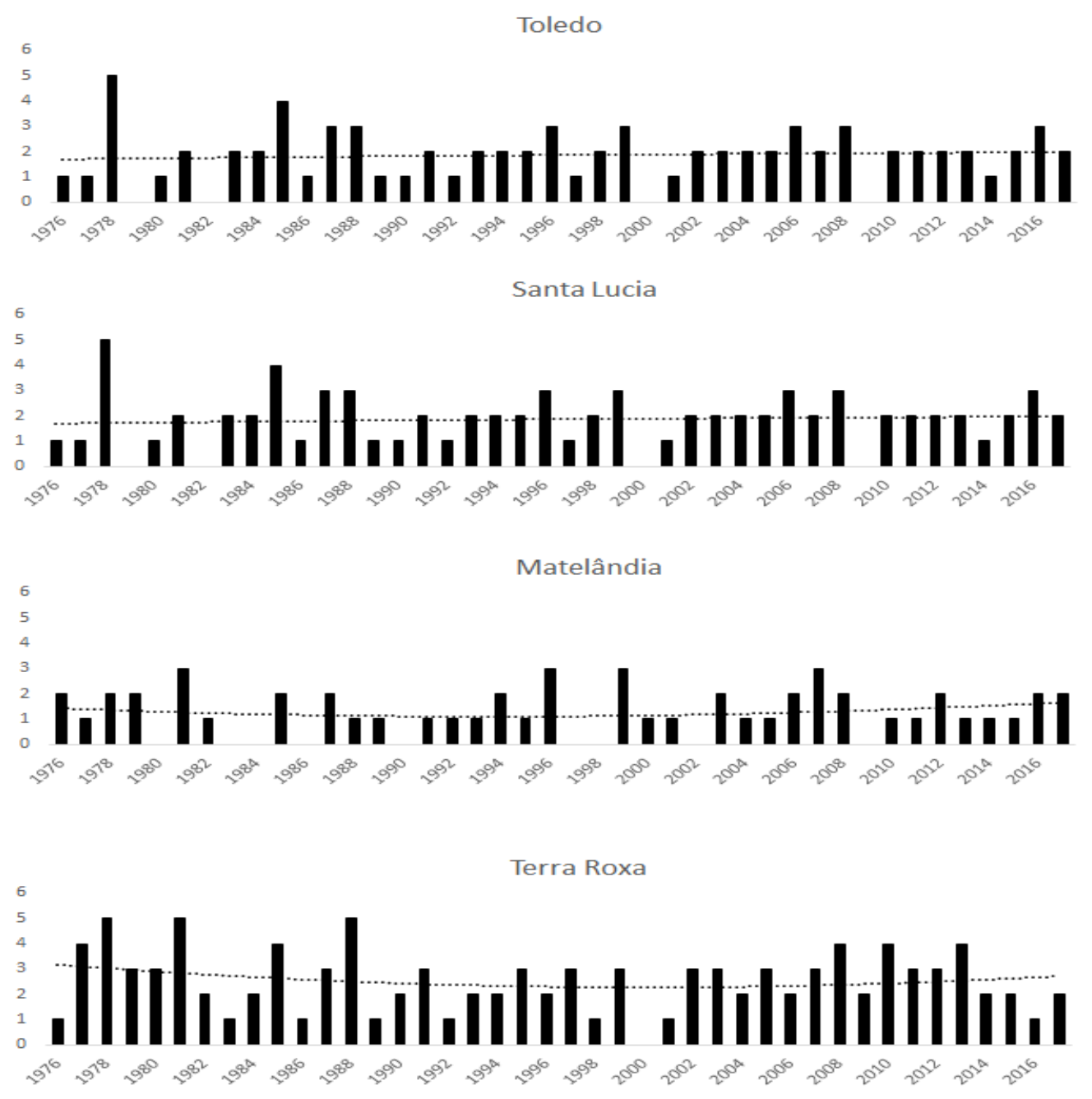

The station with the lowest number of occurrences was in the municipality of Matelândia, with 53 occurrences during the analyzed series. We identified four years in the series without any occurrence of rain within 20 days.

It is should be noted that even considering the Basin of Paraná River III as a rainy location, the risks of dry days reach at least 20 days, ranging from 80 to $90 \%$ of risks. 


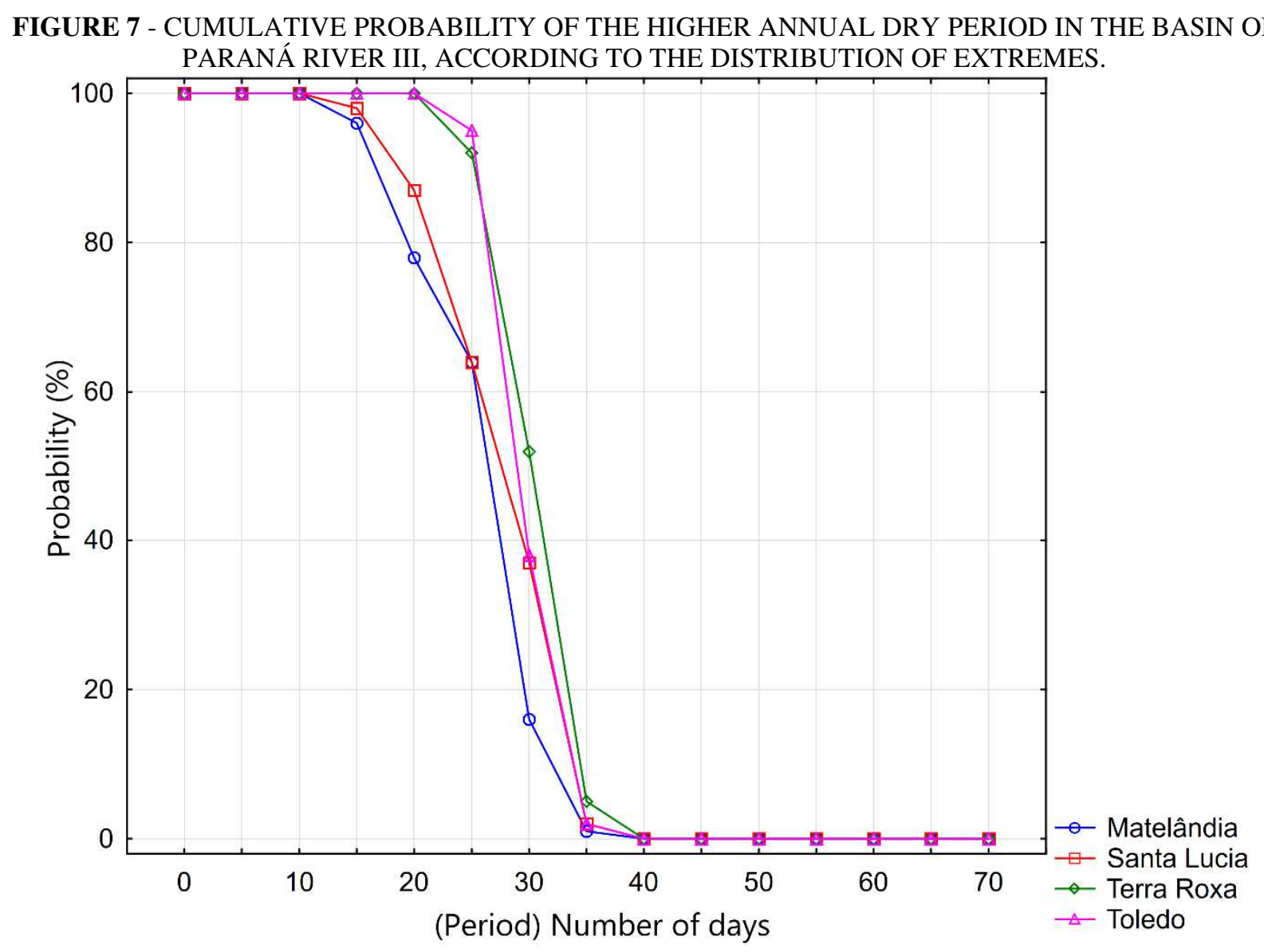

The risk of more than 35 days without rain is practically inexistent, while from 40 consecutive days without precipitation, it is zero. For the context agriculture and crops productions, 30 days without rain can be determine the crop failure, in the field. Species, mainly fruit and arboreal species are more resistant due they have an effective depth of the deepest roots (CALDANA et al., 2020). On the other hand, it is should be noted that also dry periods can be favorable for fruit species, due the development of the profitability of fruit commercialization. While for the climatological water balance of the region (Figure 08), it was identified that every month at the Cascavel station, São Miguel do Iguaçu and Toledo presented water surplus, demonstrating that for the annual average, for species cultivated with deep roots of at least $30 \mathrm{~cm}$, there is no water stress caused by disability. However, atypical years, with rainfall well below the average, as in 1979 (Figure 02), may present discrepancies in the water balance. 
FIGURE 8 - WATER BALANCE IN THE BASIN OF PARANÁ RIVER III

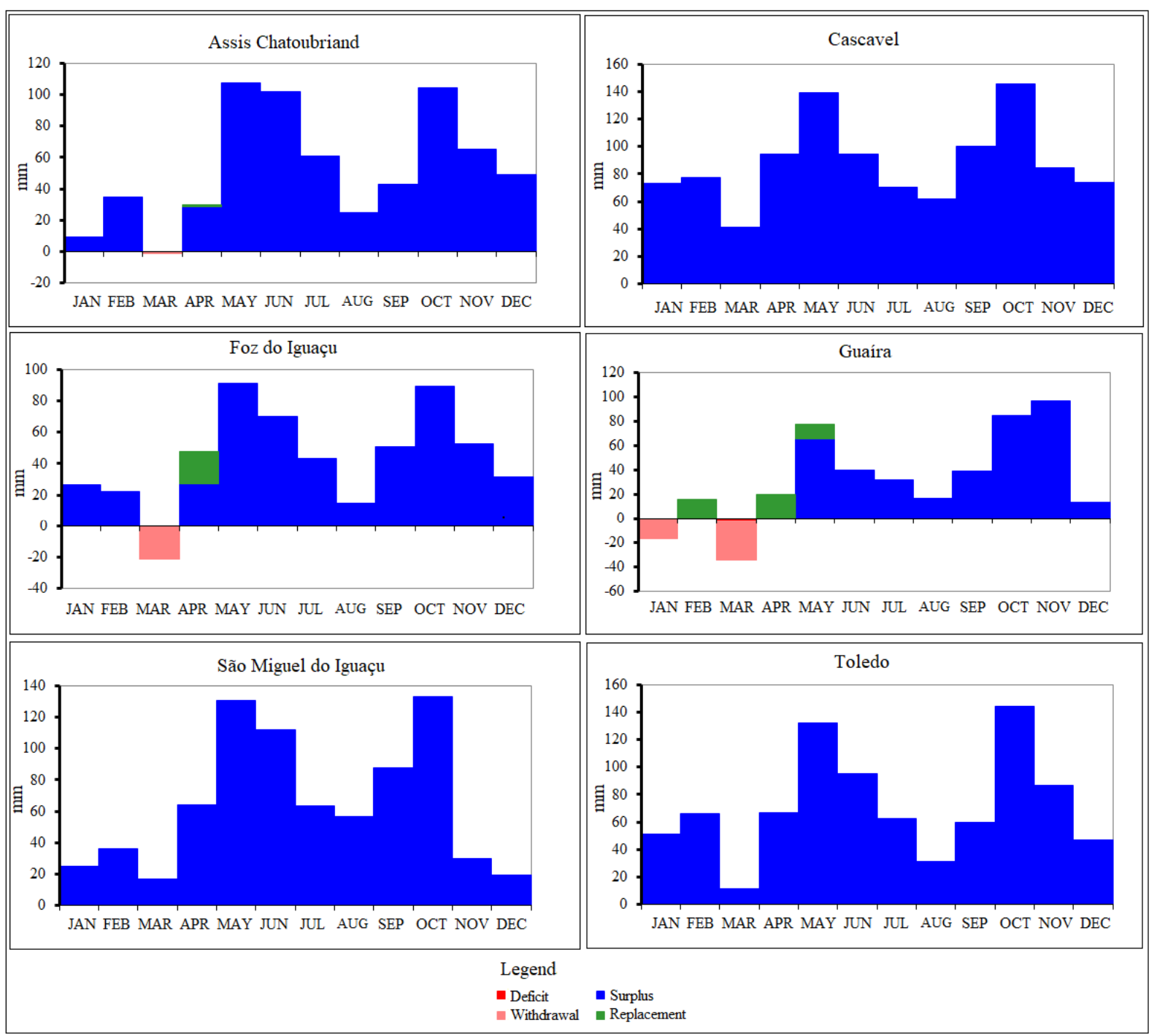

The municipality of Assis Chateabreand exhibited only $1.2 \mathrm{~mm}$ of deficit in March. The municipalities Foz Iguaçu and Guaíra presented water deficiency in the month of March with more accentuated values, being 22 and $37 \mathrm{~mm}$, respectively. The replacement in Guaíra is completed only in the month of May. In Guaíra was verified deficiency in the annual accumulated with $56 \mathrm{~mm}$

However dry periods can occur in the basin of Paraná river III. This affects the water balance and can have severe impacts on crops production in the area of the study. Due to the average climatological water balance, only Guaíra was water deficient, however, when analyzing the dry years (Figure 12), it was identified that the entire region can present high values of water withdrawal from the soil and water deficiency. 
FIGURE 9 - WATER BALANCE FOR DIFFERENT SCENARIOS DURING DRY PERIODS IN THE BASIN OF PARANÁ RIVER III
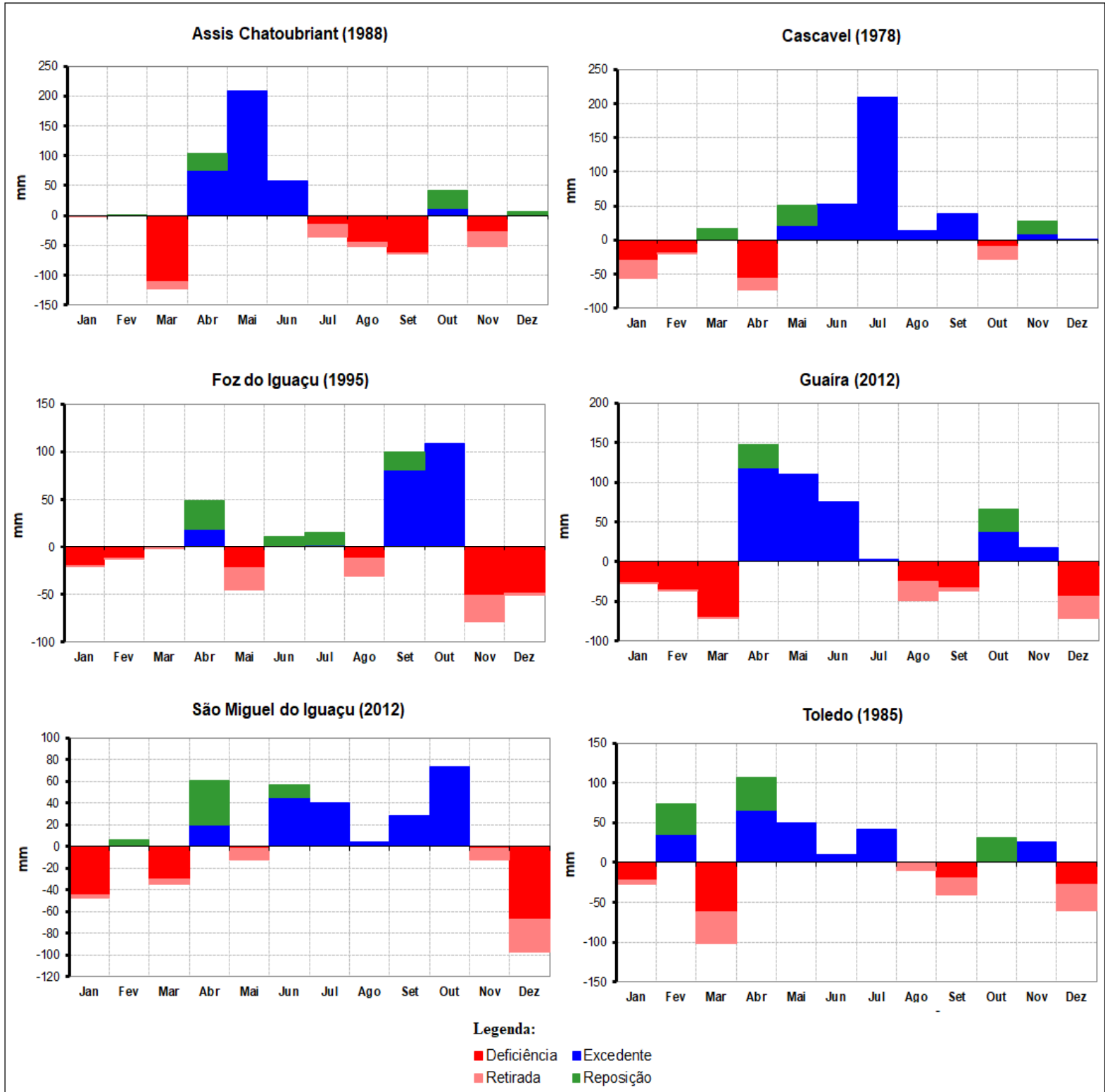

In the municipality of Assis Chateaubriand, in 1988, the water deficiency in March exceeded $100 \mathrm{~mm}$, while the removal of water in the soil in Toledo and São Miguel do Iguaçu, in 1985 and 2012, respectively, also exceeded $100 \mathrm{~mm}$. In the dry years analyzed, the values are more alarming in the spring and summer seasons, since, even though the seasons are the rainiest (Figure 04), they are the warmest in the region (CALDANA et al., 2019), and this increases evapotranspiration and evaporation, and consequently has a negative impact on water balance, when dry periods occur in these months. 


\section{CONCLUSIONS}

- Precipitation in the basin of Paraná River III exhibited a local climate discrepancy. The annual average variability verified was from $1,550 \mathrm{~mm}$ in the far Northern of the basin to 2,125 $\mathrm{mm}$ in the East. The topography, altitude and formation of atmospheric instabilities justify the differences observed in this study.

- Monthly, the basin necessities of appropriate agricultural planning management and other agricultural activities. The precipitation may variate, in the same month, from 2.5 to $557 \mathrm{~mm}$.

- Even though it is a rainy region of the Paraná state, the occurrence of dry spells is significant during certain times of the year, ranging from zero to more than $60 \%$ of risk of occurrences in the basin of Paraná river III. The periods with the lowest risk verified are October, followed by December 10 to January 5.

- Periods of 20 to 30 days without rain in the region were also frequent, with a risk of annual occurrence ranging from 80 to $50 \%$, respectively. However, the risk of 40 consecutive days without rain has already proved to be insignificant.

- The annual average water balance exhibited sufficient values for agricultural practice with water, in the basin of Paraná River III. However, when analyzing dry years, a water deficit of more than 100 $\mathrm{mm}$ in a single month can occur, demonstrating the importance of this study and agricultural planning and decision-making.

\section{REFERENCES}

ADHIKARI, U. et al. Climate change and eastern Africa: a review of impact on major crops. Food and Energy Security, v. 4, n. 2, p. 110-132, 2015.

CALDANA et al., Agroclimatic Risk Zoning of Avocado (Persea americana) in the Hydrographic Basin of Paraná River III, Brazil. Agriculture, v. 9, n. 263, p. 1-11, 2019

CIDADE, L. C. F. Urbanização, ambiente, risco e vulnerabilidade: em busca de uma construção interdisciplinar. Cadernos Metrópole, v. 15, n. 29, p. 171-191, 2013.

DANTAS, A. A. A. et al. Classificação e tendências climáticas em Lavras, MG. Ciência e Agrotecnologia, v. 31, n. 6, p. 1862-1866, 2007.

DINIZ, J. M. T. Variabilidade da precipitação e do número de dias com chuvas de duas cidades distintas da Paraíba. Holos, v. 3, p. 171-180, 2013.

DONG, F. et al. A season-specific, multi-site calibration strategy to study the hydrological cycle and the impact of extreme-flow events along an urban-to-agricultural gradient. Ecological Informatics, p. 100993, 2019. 
IPCC, 2014: Climate Change 2014: Synthesis Report. Contribution of Working Groups I, II and III to the Fifth Assessment Report of the Intergovernmental Panel on Climate Change [Core Writing Team, R.K. Pachauri and L.A. Meyer (eds.)]. IPCC, Geneva, Switzerland, 151 pp.

GEBRECHORKOS, S. H. et al. Impacts of projected change in climate on water balance in basins of East Africa. Science of The Total Environment, v. 682, p. 160-170, 2019.

GRIGOLETTI, G. de C. et al. Microclima urbano de áreas residenciais no período noturno: Estudo em Santa Maria, RS. Revista Sociedade \& Natureza, v. 30, n. 2, p. 140-163, 2018.

FITTON, N. et al. The vulnerabilities of agricultural land and food production to future water scarcity. Global Environmental Change, v. 58, p. 101944, 2019.

FOLHES, M. T; DONALD, N. Previsões tradicionais de tempo e clima no Ceará: o conhecimento popular à serviço da ciência. Sociedade \& Natureza, v. 19, n. 2, p. 19-31, 2007.

FREIRE, N. B. C. et al. Vulnerabilidade socioambiental, inundações e repercussões na Saúde em regiões periféricas: o caso de Alagoas, Brasil. Ciência \& Saúde Coletiva, v. 19, p. 3755-3762, 2014.

$\mathrm{KANG}, \mathrm{H}$. et al. Economy-wide climate change impacts on green water droughts based on the hydrologic simulations. Agricultural systems, v. 171, p. 76-88, 2019.

MALLUCCI, S. et al. Detection and attribution of hydrological changes in a large Alpine river basin. Journal of Hydrology, 2019.

MARCELINO, E. V.; Desastres Naturais e Geotecnologias: Conceitos Básicos. INPE, Santa Maria, 2007.

MARENGO, J. A. et al. Future change of climate in South America in the late twenty-first century: intercomparison of scenarios from three regional climate models. Climate Dynamics, v. 35, n. 6, p. 1073-1097, 2010.

MARENGO, José A. O futuro clima do Brasil. Revista USP, n. 103, p. 25-32, 2014.

PEREIRA, A. R.; ANGELOCCI, L. R; SENTELHAS, P. C. Agrometeorologia: fundamentos e aplicações práticas. 2002.

SATGÉ, F. et al. Unraveling the impacts of droughts and agricultural intensification on the Altiplano water resources. Agricultural and Forest Meteorology, v. 279, p. 107710, 2019.

SATO, M. et al. Adverse environmental health effects of ultra-low relative humidity indoor air. Journal of occupational health, v. 45, n. 2, p. 133-136, 2003.

SERDECZNY, O. et al. Climate change impacts in Sub-Saharan Africa: from physical changes to their social repercussions. Regional Environmental Change, v. 17, n. 6, p. 1585-1600, 2017.

SIAD, Si Mokrane et al. A review of coupled hydrologic and crop growth models. Agricultural Water Management, v. 224, p. 105746, 2019.

DA SILVA DIAS, M. A. F. Eventos climáticos extremos. Revista USP, n. 103, p. 33-40, 2014. 
SUN, F. et al. Projecting meteorological, hydrological and agricultural droughts for the Yangtze River basin. Science of The Total Environment, p. 134076, 2019.

THORNTHWAITE, C.W., MATHER, J.R. The water balance. Centerton: Laboratory of Climatology. Publications in Climatology, v.8, n.1. 104 p, 1955.

THORNTON, P. K. et al. Agriculture and food systems in sub-Saharan Africa in a 4 C+ world. Philosophical Transactions of the Royal Society A: Mathematical, Physical and Engineering Sciences, v. 369, n. 1934, p. 117-136, 2011.

XIE, M. et al. Mechanisms of radical-initiated methylmercury degradation in soil with coexisting Fe and $\mathrm{Cu}$. Science of The Total Environment, v. 652, p. 52-58, 2019.

XIONG, Y. et al. Effects of relative humidity on animal health and welfare. Journal of integrative agriculture, v. 16, n. 8, p. 1653-1658, 2017.

ZHANG, Y. et al. Evaluating storage and pool size of soil organic carbon in degraded soils: Tillage effects when crop residue is returned. Soil and Tillage Research, v. 192, p. 215-221, 2019. 